\title{
As poderosas argúcias da palavra literária*
}

Maria Velho da Costa deixou, em 0 Livro do Meio (2006), escrito a meias com Armando Silva Carvalho, um curioso registo de nascimento que transforma a história em destino: "Nasci na madrugada de 26 [de Junho: o mês tinha sido referido algumas linhas atrás], às três da manhã, um domingo. A Sunday Child, dizem os ingleses que é criança solar". É interessante lembrar que uma lenda popular cristã também nomeia as "crianças de domingo", atribuindo-lhe poderes sobrenaturais, tais como o de compreender a língua dos pássaros. A arte de mimetizar linguagens que não eram as do seu meio foi uma faculdade que desenvolveu e explorou com uma aguda consciência da matéria linguística investida na palavra literária. A criança de domingo, quando já era uma escritora reconhecida e prestigiada, utilizou uma expressão em Casas Pardas (1977), que vale por um conceito hiperbólico: "crioulo galáctico". Este conceito traduz a capacidade de recodificar e universalizar linguagens nascidas em ambientes culturais e sociais restritos ou marginais, linguagens que muitas vezes emergem de diferenças e conflitos sociais ou de clivagens históricas. E isso foi bem visível desde o seu primeiro romance, Maina Mendes, de 1969. É verdade que se estava em plena época de experimentação textual e de atenção privilegiada ao significante (para utilizarmos a metalinguagem que tinha triunfado), às vezes próxima de uma exasperação barroca. Mas em nenhum momento Maria Velho da Costa se deixou arrastar para qualquer dimensão gratuita, inócua, ou para o ludismo virtuoso sem consequências. Muito embora tenha experimentado em Irene ou o Contrato Social - um título que a autora classificou de "sardónico" - entrar num "jogo arriscado" (disse-o numa entrevista, sem especificar o sentido desse risco, mas podemos intuir que se refere ao facto de esse livro ser uma espécie de fábula que representa um forte cepticismo em relação a um contrato social da literatura).

Praticou a carnavalização das linguagens, integrou uma enorme variedade de sociolectos, exibiu uma vocação literária que poderíamos dizer que é de ordem babélica, mas não foi auto-complacente com os seus virtuosismos e sempre os pôs ao serviço de uma escrita narrativa que construiu poderosos universos colectivos e pessoais. Em toda a sua obra, mas com uma força excepcional nos seus dois últimos romances, Irene ou o Contrato Social (2000) e Myra (2008), podemos apreciar a incidência social sem sociologismos e o alcance político sem conteudismos enfraquecedores ou mensagens transparentes. Podemos dizer, sem grandes hesitações, que neste seu último romance a linguagem reinventa-se e manifesta-se num estado próximo do delírio. Myra, a protagonista, é uma adolescente russa, em Portugal, que empreende uma viagem de regresso, em direcção ao Leste, ao longo da qual atravessa 
Cadernos de Literatura Comparada

As poderosas argúcias da palavra literária

diferentes linguagens e diversos discursos sócio-ideológicos. Nessa espécie de viagem iniciática ao contrário, Myra situa-se numa posição de estrangeira, de pária, de descentrada em relação à língua materna. Por conseguinte, o dialogismo deste romance - e a arte do romance de Maria Velho da Costa tem características dialógicas ou polifónicas - é também o da Babel de línguas (russo, alemão, inglês) a que se junta a Babel dos sociolectos. E a coroar tudo isto, como uma espécie de esperanto, temos o crioulo.

Sempre se manteve fiel a uma concepção da literatura que recusa as alienações ideológicas e políticas. Mais do que isso: a palavra literária foi, para ela, uma subversão do discurso gnómico e tético. Talvez por isso, recusou com veemência o estatuto de intelectual ou de escritora de ideias. E, numa entrevista, chegou mesmo a reclamar: "Não escrevo para transmitir ideias" e "Não sou nada programática nem tenho a mínima intenção de resolver problemas sociais com aquilo que escrevo. Se tivesse, escrevia ensaios ou tinha uma actividade cívica e política mais intensa". Já por altura das Novas Cartas Portuguesas (1972) reivindicou uma atitude em relação à escrita literária que rejeitava a sua redução a mero veículo. E isso tornar-se-ia a razão suficiente para sentir alguma incomodidade perante esse livro que deu origem a um clamor internacional por causa do acto de censura a que a polícia política o submeteu. Nas visões retrospectivas do seu percurso literário, quando foi solicitada a falar do conjunto da sua obra, várias vezes manifestou uma certa distância em relação a esse livro colectivo. Sem o renegar, mas manifestando alguma impaciência quando via o seu nome de escritora amplificado pelos ecos extra-literários que a publicação desse livro provocou, tornou bem claro que não era como uma das "três Marias" que gostava de ser referida.

Maria Velho da Costa foi uma escritora intensa e de intensidades. Não foi uma autora prolífera, em nenhum momento do seu percurso teve uma produção abundante e sempre houve longos intervalos entre as suas publicações. Por exemplo, entre o romance Missa in Albis (1988) e o livro que veio a seguir, um volume de contos intitulado Dores, com reprodução de telas de Teresa Dias Coelho, houve um hiato de seis anos. Desse longo intervalo, nasceram histórias de uma luz negra e de momentos terminais. Esse tom não foi de modo nenhum uma surpresa: mesmo quando parece mais solar e indulgente, a escrita de Maria Velho da Costa nunca deixa de ser negra e cruel, há nela uma força de engendramento que está vinculada à consciência do mal, cujos desígnios ela parecia conhecer como nenhum outro escritor português contemporâneo. A literatura e o mal, os dois termos de uma equação que Bataille formulou para alguns autores da literatura francesa, também faz parte dos "cálculos" da escritora Maria Velho da Costa: o mal foi, de maneira recorrente, a sua "matéria de Bretanha". Ao ponto de entrar com gáudio na deleitação imoral, como acontece em o Livro do Meio, quando se apropria - fazendo disso uma arma que exibe ao seu interlocutor, Armando Silva Carvalho - de uma tirada imoralista de Madame de Merteuil, a libertina de As Ligações Perigosas: "Posso bem passar sem as qualidades que não tenho".

Fácil é assim perceber que uma das razões da sua admiração por Agustina Bessa-Luís, que considerava "a autora da grande obra novelística da literatura portuguesa deste século", era a "compaixão distanciada" da autora da Sibila, para a qual, disse Maria Velho da Costa 
numa entrevista, "os seres humanos são muito interessantes, mas são paisagística. Ela está interessada em divertir, encantar, ridicularizar, vingar-se". Para logo a seguir acrescentar: "Devo dizer que, neste aspecto, não estou assim tão distante". Outro génio do mal pelo qual teve uma grande admiração é João César Monteiro. É aliás o cinema que suscitou os seus maiores entusiasmos artísticos: "porque integra simultaneamente todas as artes, sejam elas a pintura, a música, a literatura, etc."

Mas também afirmou a sua grande admiração por escritores em relação aos quais não tinha quaisquer afinidades electivas, mostrando assim o quanto era abrangente. Por exemplo, Maria Gabriela Llansol, autora de "objectos insólitos e singularíssimos". Na posição mais elevada do seu panteão, estavam Camões e Guimarães Rosa. A inclusão deste autor maior da literatura brasileira do século XX é fácil de perceber: ele praticou como mais ninguém na literatura de língua portuguesa a acumulação não hierárquica das linguagens. Conciliou na perfeição o trabalho linguístico, a dimensão cognitiva e a técnica narrativa mais apurada. Foi também a esta tripla exigência que Maria Velho da Costa tentou responder com o sentido de que não há grandes clivagens entre a ética e a estética - uma lição aprendida em autores decisivos do modernismo literário.

O Livro do Meio é, de certo modo, um objecto insólito na obra de Maria Velho da Costa e cumpre, nalguns aspectos, uma função autobiográfica ou de livro de memórias. Recupera processos do romance epistolar, mas não se trata de uma correspondência cordial entre dois amigos e cúmplices, ambos dados à crítica afiada e à observação satírica e até jocosa, ministradas em requintada linguagem. Há momentos de guerra, teatralizada à maneira dos dois libertinos de Ligações Perigosas, a Madame de Merteuil e o Visconde de Valmont, os quais comparecem a todo o momento como figuras de evocação. E o motivo é uma diferença de classes, que Maria Velho da Costa tenta esbater, ao mesmo tempo que a suscita como tema da sua troca epistolar. A resposta que obtém é a de um desclassificado social de nascimento - Armando Silva Carvalho - que entra satiricamente e a contragosto neste jogo da luta de classes e de distinções simbólicas: a menina lisboeta de boas famílias do lado do pai (um militar, neto do último morgado da Messejana), escolarizada num colégio de freiras, o Colégio das Escravas, na Lapa, até quase ao fim do último ciclo do Colégio, antes da entrada na Universidade, contra o menino da aldeia, nascido em ambiente rural e educado na escola pública. Quem percorrer com atenção toda a obra literária da escritora descobre facilmente o leitmotiv da classe, dos seus códigos e sinais de reconhecimento. É uma marca profunda, sempre a retornar, como o recalcado, aquela que foi inscrita na menina e adolescente Maria de Fátima de Bivar Velho da Costa nesses anos do colégio frequentado pelas meninas da elite social e financeira de Lisboa. Foi aí, e não em casa, que ganhou uma consciência aguda do sistema social das castas.

Só por contingência conjugal, o casamento aos 23 anos com Adérito Sedas Nunes, que fazia parte dos meios católicos de esquerda, é que esteve próxima dos círculos intelectuais. Foi aí que completou uma deficiente formação artística e literária. Também nunca empunhou com força e conviç̧ão a bandeira ideológica do feminismo. E pôde até arriscar afir- 
mações que se aproximam da visão essencialista da mulher e da sua relação íntima com uma suposta "natureza". Ouvimo-la dizer, numa entrevista, em 2001, depois de Irene... ter ganho o Prémio do Romance e Novela da APE: "As figuras femininas estão potencialmente mais próximas da fala elementar, das relações com os animais, com as crianças e, eventualmente, em situação trágica, levantam mais facilmente a cabeça para a linguagem cósmica. Há potencialmente uma labilidade maior na consciência feminina do que na masculina".

Mas o seu modo de se pôr à distância de certos ambientes ideológico-políticos e de pessoas que frequentou nunca é um renegar ressentido. Por exemplo, por algum tempo, breve, aderiu ao Partido Comunista. Mas saiu logo em 1977, sem dramas nem traições. Diríamos, se tentássemos imitar a sua linguagem, sem inépcias nem malfeitorias, por "incoincidência". Incoincidências, terá muitas, até com grandes amigos. De certo modo, O Livro do Meio, ao contrário do que possa parecer, é também a história de uma "incoincidência" com o amigo Armando Silva Carvalho. Era uma amizade que dava luta e originava tensões. Muito produtiva, portanto, como ficou demonstrado. De resto, em matéria de afectos, Maria Velho da Costa tem uma história de grandes investimentos e iguais desinvestimentos. As pequenas glórias que o mundo literário e artístico faculta nunca substituíram as suas necessidades afectivas, embora, como é natural, tivesse sido nesse mundo que encontrou muitos dos seus amigos: a Sophia, a Menez, o Manuel Gusmão, o Armando, a Margarida Gil, o César Monteiro, a Isabel Allegro de Magalhães. Mas, como regra a seguir, nunca teve dúvidas de que os afectos são flutuantes e de que admiti-lo é um princípio de prudência e uma prova de auto-consciência. "Os Afectos Flutuantes", lembremos, é precisamente o título de um capítulo de O Livro do Meio, onde Maria Velho da Costa mostra que a literatura foi, para ela, a actividade mais inocente e, ao mesmo tempo, um exercício de pura maldade.

\footnotetext{
* Este texto integra algumas partes já publicadas na Revista Electra, nº 3, de 2018.
} 